\title{
An insight into the dairy chain of a Protected Designation of Origin cheese: The case study of Asiago cheese
}

\author{
I. Lora, (ㄱ) A. Zidi, L. Magrin, (1) P. Prevedello, and G. Cozzi* (이 \\ Department of Animal Medicine, Production and Health, University of Padova, Viale dell'Università 16, Legnaro (Padova) 35020 , Italy
}

\begin{abstract}
The Protected Designation of Origin (PDO) label of the European Union safeguards and guarantees topquality traditional agri-food products that must be manufactured in a specific region according to traditional production methods. Production specifications of PDO cheeses are often focused on the cheese-making process and lack information on the dairy farming system that is upstream of the chain. This case study aimed to analyze and cluster the dairy farms that supply milk to the chain of Asiago, an internationally known PDO cheese of northeastern Italy. A large survey involving all of the cheese factories of the Asiago PDO chain was made in 2017. Each cheese factory submitted a questionnaire to its supplying dairy farmers concerning (1) farm facilities and herd management and (2) feeding program of lactating cows. Results from 517 farms were processed; there were $67 \pm 27 \%$ (mean \pm standard deviation) respondents per cheese factory. Four clusters of dairy farms were identified by hierarchical clustering analysis. Cluster 1 ( $8 \%$ of the surveyed farms) and cluster $2(22 \%)$ are small in size and low in yield, representing the traditional milk production system; farms are mainly located on mountains or hills and have autochthonous dual-purpose breeds mostly housed in tiestall barns. By rearing cattle of endangered breeds and feeding cows primarily with forages produced onfarm together with the use of pasture, these clusters, and especially cluster 1 , have shown to provide essential ecosystem services for landscape and biodiversity preservation in the alpine areas. Clusters 3 and 4 (34 and $36 \%$ of the surveyed farms, respectively) gather medium-scale farms mainly located in the lowland that operate according to modern management and housing systems and rear high-producing dairy cows. These cows are mainly fed total mixed rations based
\end{abstract}

Received August 21, 2019.

Accepted May 11, 2020.

*Corresponding author: giulio.cozzi@unipd.it on corn silage, but the dietary forage:concentrate ratio is kept relatively high, as farmers are more interested in producing high-quality milk for cheese-making than pushing for yield. Regardless of the cluster allocation, a considerable cow longevity, which is a recognized "iceberg indicator" of cattle well-being, was highlighted. This study showed that different farming systems may lay behind a single PDO cheese. The knowledge of their characteristics is important to reinforce the PDO production specifications as well as to distinguish and protect niche products that come from specific groups of farms that provide essential ecosystem services.

Key words: dairy cow, Asiago cheese, protected designation of origin, farming system

\section{INTRODUCTION}

The Protected Designation of Origin $(\mathbf{P D O})$ is a label created by the European Union to promote and protect agricultural food products produced and manufactured in a specific geographical area using local ingredients and a recognized methodology (European Commission, 2012). The PDO labeled foodstuffs are high-quality products strictly linked to local traditions with rigorously defined specifications for their production processes. The European Union has assigned the PDO label to more than 180 cheeses that represent a relevant share of the global cheese market. Italy is the country with the largest number of registered PDO cheeses, which include 50 different varieties (DOOR, 2018). Among those made from cow milk, Asiago is the fourth most produced PDO cheese at the national level, with about 21,000 $\mathrm{t}$ produced and 1,700 $\mathrm{t}$ exported in 2017. The United States, Switzerland, Australia, Germany, and France are the main importing countries of Asiago PDO cheese (Clal, 2018).

Asiago PDO is a semi-cooked, semi-hard cheese that originates from a mountainous dairy-farming area located in a plateau of the Italian Eastern Pre-Alps. The Asiago PDO cheese-making process is described and protected "from farm to fork" by an official regulation (Consortium for the Protection of Asiago Cheese, 2006) 
that sets the geographical area of milk origin and the specific guidelines for cheese production. As with many other PDO cheeses, Asiago PDO production specifications do not deal with the farming system upstream of the cheese production chain, with only a few indications addressed to ban some specific by-products from the cows' feeding programs. It is well known, however, that cattle breed and management practices may affect milk composition as well as the nutritional and organoleptic profile of dairy products (De Marchi et al., 2008; Larsen et al., 2010; Gulati et al., 2018). So far, several authors have studied the cheese-making process, the main quality traits (Schievano et al., 2008; Cozzi et al., 2009; Balzan et al., 2013), and the sustainability (Dalla Riva et al., 2018) of Asiago PDO cheese, but no data are available in the literature to describe the farming systems that are upstream of the cheese chain. To fill this gap, the present study aimed to identify and cluster the type of farms that supply milk to the Asiago PDO chain. Such information is essential to plan for any improvement to the cheese quality, to identify the existence of particular niches of product, as well as to gather information about specific indicators of cow welfare. Moreover, it could be useful to support the fight against illegal PDO cheese imitations, as Asiago is one of the most plagiarized cheeses around the world. The approach proposed in this study for Asiago cheese can also be applied to other PDO products.

\section{MATERIALS AND METHODS}

\section{Data Collection}

A large survey was carried out in 2017 in collaboration with the Consortium for the Protection of Asiago Cheese and involved all of the 22 cheese factories that produce Asiago PDO. A specific questionnaire was created and divided into 2 main sections: (1) farm and herd management description and (2) feeding program of lactating cows. The first section included 10 questions on farm location, herd size, cattle breed, average age at first calving, average number of lactations, average milk yield per lactation, housing system, feeding system, milking system, and the use of pasture. The second section addressed the feed composition of the average diet provided to the lactating cows. Type and amounts of forages and concentrate feeds were recorded to calculate the total DM of the diet. The list of questions, the answer options, and the classification of the variables used for the following statistical analysis are reported in Table 1. Each cheese-factory manager was in charge of distributing and collecting the questionnaires from his supplying dairy farmers. The questionnaires were filled in from January to March 2017, and all of the information gathered referred to the year 2016 .

\section{Statistical Analysis}

Statistical analysis was performed using $\mathrm{R}$ version 3.4.4 (R Core Team, 2018). Farms were classified based on data from the first section of the questionnaire. The dimension of features (quantitative and qualitative variables) was reduced using a clustering approach (ClustOfVar R package; Chavent et al., 2012) and new synthetic variables were calculated that represented the new matrix of data for further analyses. The optimum number of clusters was determined using the stability of partition criteria. Eigenvalues were calculated (FactoExtra $\mathrm{R}$ package) and the principal components with eigenvalues $>1$ were retained for the hierarchical cluster analysis of the farms (FactoMineR R package; Lê et al., 2008). Clusters were characterized and compared using means and standard deviations for continuous variables or frequencies in the case of binomial variables. For continuous variables, differences between clusters were estimated using a one-way ANOVA and post hoc pairwise comparisons were performed using Tukey's correction. For categorical variables, differences between clusters were estimated by chi-square test. The level of significance was set at $P<0.05$.

\section{RESULTS}

Questionnaires were filled in from 540 dairy farms of the Asiago PDO cheese chain, representing about $69 \%$ of the overall farms involved in the supply chain, with an average percentage of respondents per cheese factory of $67 \pm 27 \%$ ( $\pm \mathrm{SD})$. Twenty-three questionnaires were discarded due to incomplete filling; thus, the final database included data from 517 dairy farms (about $66 \%$ of the overall farms of the supply chain).

The ClustOfVar analysis generated 5 synthetic variables from the original data corresponding to the following original features: (1) number of cows, average milk yield per lactation; (2) average age at first calving, percentage of Italian Simmental cows; (3) percentages of Italian Brown and Holstein cows; (4) percentage of local breeds; and (5) farm location, housing system, feeding system, milking system, and use of pasture. The principal components of the new synthetic matrix revealed that only the first 2 dimensions accomplished the criteria of eigenvalue $>1$, which explained $\sim 51 \%$ of the total variance. The hierarchical clustering analysis identified 4 clusters of dairy farms referred to as $\mathrm{C} 1$, 
Table 1. Questions submitted to the farmers and classification of the variables considered in the study

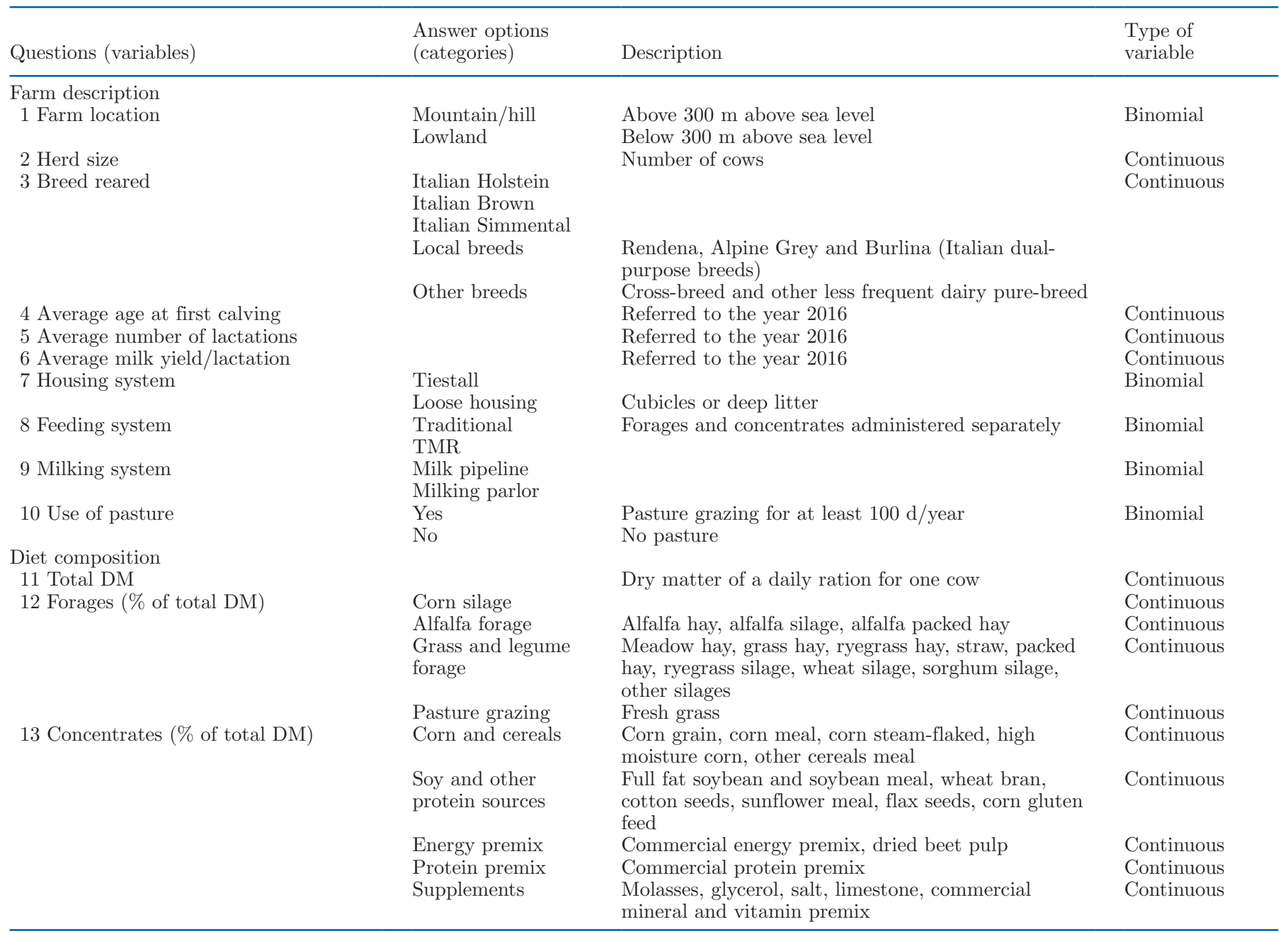

C2, C3, and C4, including $42(8.1 \%), 114(22.1 \%), 175$ $(33.8 \%)$, and $186(36.0 \%)$ farms, respectively.

\section{Cluster 1: Small-Scale Traditional Mountain and Hill Farms}

Farms of $\mathrm{C} 1$ ( $\mathrm{n}=42,8.1 \%$ of the total sample) had the smallest herd size and reared mainly Italian Simmental, Italian Brown, and local dual-purpose breed cows. This cluster had the lowest percentage of Italian Holstein cows in comparison with all of the others $(P<$ 0.05; Table 2). Farms were mostly located on mountains and hills $(62 \%)$; tiestall was the predominant housing system $(81 \%)$, and milking was performed at the stall by pipeline system (81\%; Figure 1). Most farms (79\%) used a traditional feeding system with a separate provision of forages and concentrates (Figure 1C). Summer grazing was used by $48 \%$ of the farms (Figure 1E). The average age at first calving was the highest among all the clusters $(P<0.05)$, whereas cow longevity (assessed by the average number of lactations) was similar to $\mathrm{C} 2$ but higher than $\mathrm{C} 3$ and $\mathrm{C} 4(P<0.05$; Table 3$)$. The average milk yield per lactation was also similar to $\mathrm{C} 2$ but lower than $\mathrm{C} 3$ and $\mathrm{C} 4(P<0.05$; Table 3$)$.

The average daily ration for cows provided the lowest amount of total DM per cow compared with the other clusters $(P<0.05)$ and had the highest percentage of forages ( $>70 \%$ of DM; $P<0.05$; Table 4 ). Local grass and legume forage represented almost $76 \%$ of the whole forage fraction, whereas the use of corn silage was very limited $(P<0.05$; Table 4$)$. Pasture grazing had the highest share of the total dietary DM compared with the other clusters $(P<0.05$; Table 4$)$. A commercial energy premix was the main ingredient of the concentrate fraction. The use of corn and other cereals was limited compared with $\mathrm{C} 3$ and $\mathrm{C} 4(P<0.05)$, and the inclusion of protein premix was the lowest compared with all other clusters $(P<0.05$; Table 4$)$. 
Table 2. Herd size and distribution of the breeds reared among clusters of dairy farms under the Asiago PDO ${ }^{1}$ cheese chain $($ overall $n=517$ )

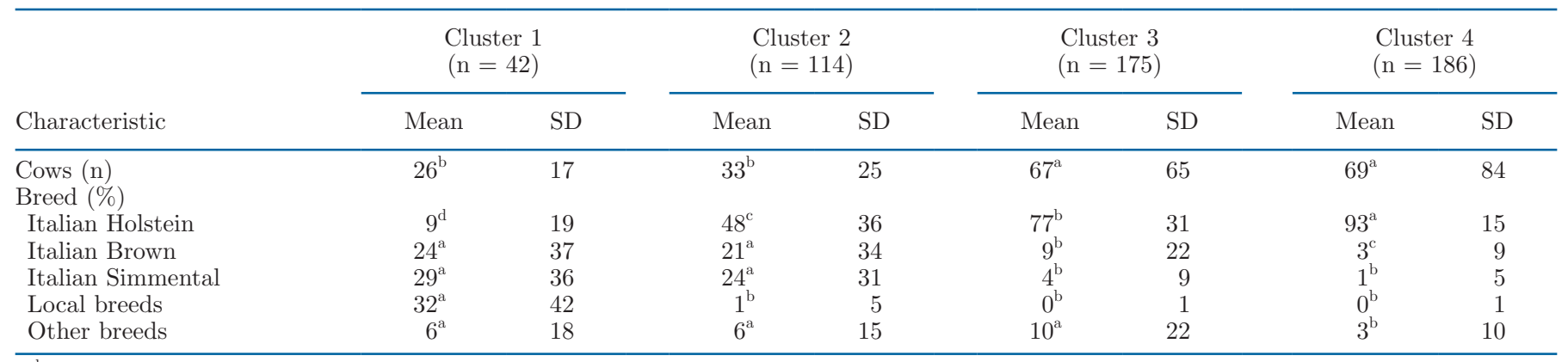

${ }^{\mathrm{a}-\mathrm{d}}$ Means within a row with different superscripts differ $(P<0.05)$.

${ }^{1} \mathrm{PDO}=$ Protected Designation of Origin .

\section{Cluster 2: Small-Scale Mountain and Hill Farms}

Farm location, herd size, housing system, feeding and milking systems, and use of pasture of $\mathrm{C} 2$ farms ( $\mathrm{n}=114,22.1 \%$ of the total sample) were similar to those of $\mathrm{C} 1$, but Italian Holstein cows replaced local dual-purpose breeds (Table 2; Figure 1). Age at first calving had an intermediate value compared with that observed in the other clusters $(P<0.05)$, whereas the number of lactations and the milk yield per lactation were similar to those observed in $\mathrm{C} 1$ (Table 3 ).

The average daily ration $\mathrm{DM}$ provided to $\mathrm{C} 2$ cows increased compared with $\mathrm{C} 1(P<0.05)$ and was similar to that of C3 and C4 (Table 4). Diet composition differed from that of $\mathrm{C} 1$ only for a lower proportion of pasture grazing $(P<0.05)$ and a higher inclusion of protein premix $(P<0.05)$, which are similar to those recorded for $\mathrm{C} 3$ and $\mathrm{C} 4$ (Table 4 ).

\section{Cluster 3: Medium-Scale Lowland Farms}

Herd size of farms in C3 $(\mathrm{n}=175,33.8 \%$ of the total sample) was more than double of that in $\mathrm{C} 1$ and C2 $(P<0.05$; Table 2). Farms were mostly located in the lowland $(73 \%)$, and cows were mainly loose-housed (61\%) in barns equipped with a milking parlor $(59 \%$; Figure 1). Italian Holstein was the predominant breed type (Table 2). Total mixed ration was the main feeding system (73\%), and the use of pasture was fairly rare (19\%; Figure 1). Both age at first calving and average number of lactations were lower than those observed for $\mathrm{C} 1$ and $\mathrm{C} 2$, but the average milk yield per lactation was higher $(P<0.05$; Table 3$)$. There were no differences between $\mathrm{C} 3$ and $\mathrm{C} 4$ for the same characteristics.

The total amount of dietary DM provided to the cows was similar to that of $\mathrm{C} 2$ and $\mathrm{C} 4$, but there was a lower inclusion of forages compared with $\mathrm{C} 2(P<0.05$; Table 4). Grass and legume forage was the main roughage of the diet, covering approximately one-third of the total DM, but it was included at a lower amount than in $\mathrm{C} 1$ and $\mathrm{C} 2$ diets $(P<0.05$; Table 4$)$. Moreover, C3 had the highest inclusion of corn silage compared with the other clusters $(P<0.05$; Table 4$)$. Regarding the concentrates, C3 diet had a higher percentage of corn and cereals and protein premix compared with both $\mathrm{C} 1$ and $\mathrm{C} 2(P<0.05$; Table 4$)$.

\section{Cluster 4: Medium-Scale Holstein Lowland Farms}

Farm features, feeding and milking systems, reproductive performance, and milk yield of $\mathrm{C} 4(\mathrm{n}=186$ farms, $36.0 \%$ of the total sample) were similar to those of C3, but almost the whole herd consisted of Italian Holstein cows (Tables 2, 3, and 4; Figure 1).

\section{DISCUSSION}

The PDO label is a fundamental tool of the European Union to safeguard and protect traditional and unique agri-food products. Because the official specifications of PDO cheeses strictly define the geographical area of production and the cheese manufacturing process, but set only minimal obligations for the farming systems that are upstream of the cheese chain, this case study aimed at providing, for the first time to our knowledge, a specific analysis of the dairy farming system that is upstream of a widely known PDO cheese, such as the Italian Asiago. Through a large survey involving all cheese factories of the Asiago PDO chain, we gathered and analyzed data from more than 500 dairy farms that supply milk to the Asiago PDO cheese chain to cluster them according to the herd size, cattle breed, management, and feeding program.

\section{Farming System}

The results of this study highlighted that different farming systems may operate behind a standardized cheese-making process of a PDO labeled product. In 
A

Farm location
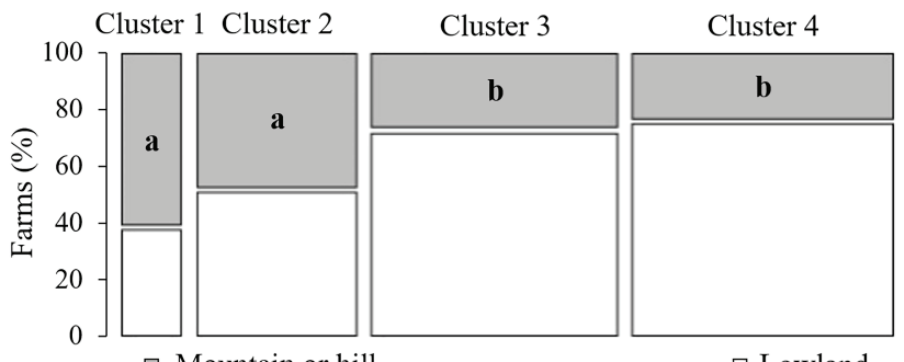

B

$\square$ Mountain or hill

Cluster 1 Cluster 2

Housing system

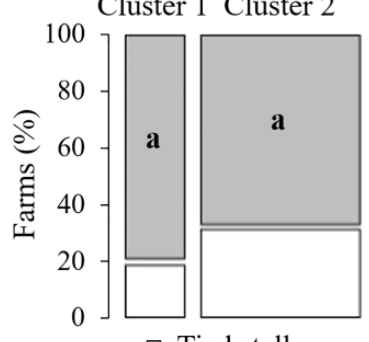

Cluster 3

$\square$ Lowland

C
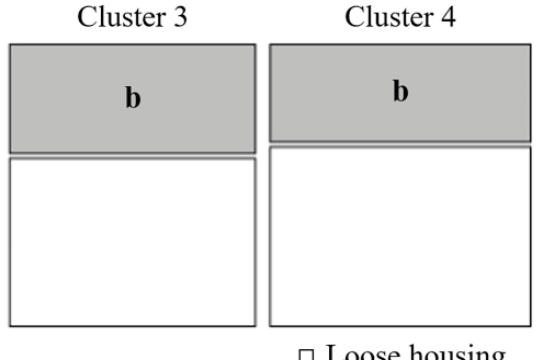

$\square$ Tied stall

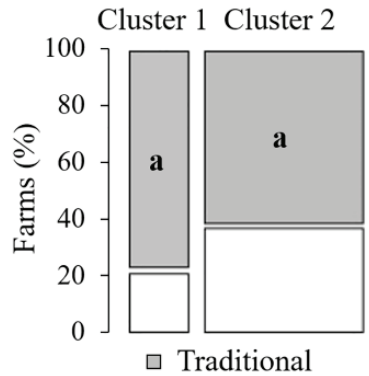

Feeding system

$\square$ Loose housing

D

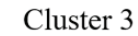

Cluster 4
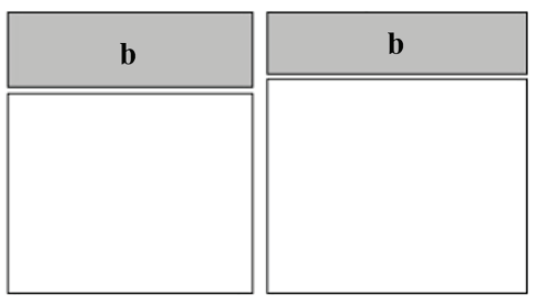

Milking system

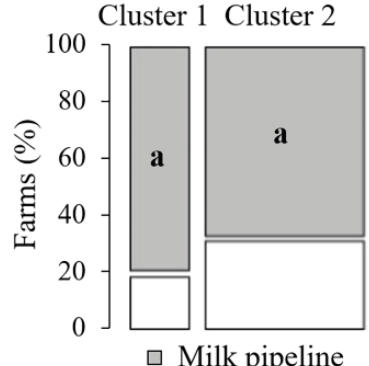

Cluster 3
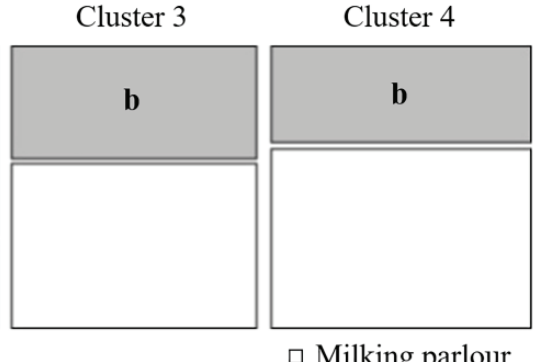

E

Use of pasture

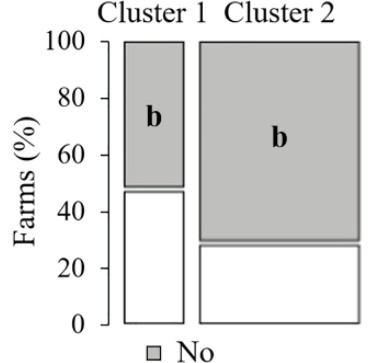

Cluster 3

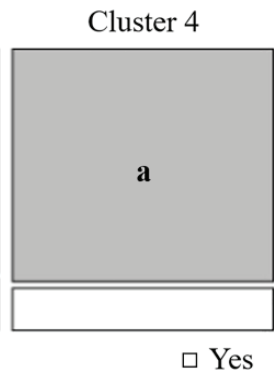

Figure 1. Description of the clusters of farms under the Asiago PDO cheese chain according to (A) farm location, (B) housing system, (C) feeding system, (D) milking system, and (E) use of pasture. Fractions of the same color with different letters $(\mathrm{a}, \mathrm{b})$ differ $(P<0.05)$. Cluster 1 $=42$ farms; cluster $2=114$ farms; cluster $3=175$ farms; cluster $4=186$ farms. PDO = Protected Designation of Origin. 
Table 3. Average age at first calving, longevity (number of lactations), and production performances of cows among clusters of dairy farms under the Asiago $\mathrm{PDO}^{1}$ cheese chain (overall $\mathrm{n}=517$ )

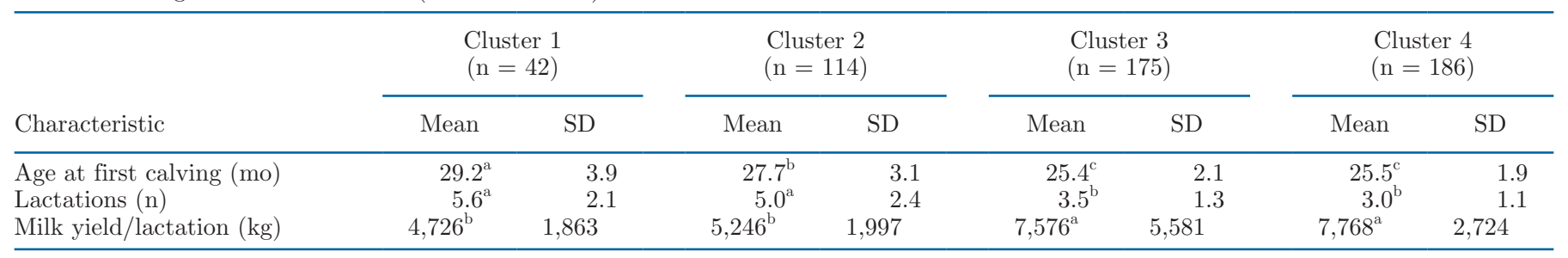

${ }^{\mathrm{a}-\mathrm{c}}$ Means within a row with different superscripts differ $(P<0.05)$.

${ }^{1} \mathrm{PDO}=$ Protected Designation of Origin.

the specific case of the Asiago PDO cheese, 4 clusters of dairy farms were identified.

Clusters 3 and 4 were predominant ( $70 \%$ of the farms involved in the survey) and represent the conventional lowland farming systems. These were modern, mediumsized farms with loose housings and a higher milk yield that is consistent with the dominant presence of the Italian Holstein cows. The lowland location and the choice of a high-producing dairy breed fully justify the limited use of both transhumance and summer grazing by these farms compared with the mountain and hill farms of C1 and C2 (Zendri et al., 2013). Average age at first calving and number of lactations recorded for C3 and C4 farms are respectively lower and higher than the reference values of 27 mo and 2.3 lactations reported at the national level by the Italian Holstein herdbook (AIA, 2017), thus suggesting a satisfactory management and welfare status of the cows belonging to these clusters. In fact, longevity (expressed as number of lactations) is considered an "iceberg" indicator of animal welfare (Bruijnis et al., 2013; Heath et al., 2014), and a lower age at first calving is linked to a higher lifetime daily milk yield (Eastham et al., 2018). The average milk yield per lactation of both C3 and $\mathrm{C} 4$ cows is lower than the reference milk yield of the Italian Holstein breed at the national level $(9,609$ kg; AIA, 2017). Farmers of the Asiago PDO chain are likely more interested in producing high-quality milk for cheese-making than in pushing for yield.

Despite being part of the same cheese chain, herd size, cattle breed, and farm management differed substantially in $\mathrm{C} 1$ and $\mathrm{C} 2$ farms, which were located mainly on mountains and hills. These farms were smaller in size than those of $\mathrm{C} 3$ and $\mathrm{C} 4$, with a predominance of tiestalls and separate feeding of forages and concentrates. In these clusters, a relevant percentage of high-producing Italian Holsteins was replaced by less-productive dual-purpose breeds that better cope with the harsh alpine environment ( Cozzi and Bizzotto, 2004; Sturaro et al., 2013; Zendri et al., 2013). Despite its small size, C1 in particular represents the typical dairy farming system from which the Asiago PDO cheese originated. Moreover, it was a reservoir of cattle biodiversity, as all the local breed types reared in these farms belong to endangered breeds, such as Rendena, Alpine Grey, and Burlina. These animals are well adapted to the typical alpine farming system that often uses summer grazing on sloped pastures.

Table 4. Typical feeding plan of cows by cluster of dairy farms under the Asiago PDO ${ }^{1}$ cheese chain (overall $\mathrm{n}=517$ )

\begin{tabular}{|c|c|c|c|c|c|c|c|c|}
\hline \multirow[b]{2}{*}{ Characteristic } & \multicolumn{2}{|c|}{$\begin{array}{l}\text { Cluster } 1 \\
(\mathrm{n}=42)\end{array}$} & \multicolumn{2}{|c|}{$\begin{array}{l}\text { Cluster } 2 \\
(\mathrm{n}=114)\end{array}$} & \multicolumn{2}{|c|}{$\begin{array}{l}\text { Cluster } 3 \\
(\mathrm{n}=175)\end{array}$} & \multicolumn{2}{|c|}{$\begin{array}{l}\text { Cluster } 4 \\
(\mathrm{n}=186)\end{array}$} \\
\hline & Mean & $\mathrm{SD}$ & Mean & SD & Mean & $\mathrm{SD}$ & Mean & SD \\
\hline Forages ( $\%$ of DM) & $73.0^{\mathrm{a}}$ & 12.3 & $69.8^{\mathrm{a}}$ & 12.2 & $61.8^{\mathrm{b}}$ & 13.7 & $60.8^{\mathrm{b}}$ & 13.3 \\
\hline Corn silage & $6.6^{\mathrm{b}}$ & 11.2 & $12.7^{\mathrm{b}}$ & 14.2 & $19.9^{\mathrm{a}}$ & 16.0 & $19.5^{\mathrm{a}}$ & 15.3 \\
\hline Alfalfa hay & 5.3 & 13.6 & 6.3 & 10.4 & 6.4 & 8.8 & 7.8 & 7.4 \\
\hline Concentrates (\% of DM) & $27.0^{\mathrm{b}}$ & 12.3 & $30.2^{\mathrm{b}}$ & 12.2 & $38.2^{\mathrm{a}}$ & 13.7 & $39.2^{\mathrm{a}}$ & 13.3 \\
\hline Corn and cereals & $6.6^{\mathrm{b}}$ & 9.7 & $8.3^{\mathrm{b}}$ & 9.7 & $14.8^{\mathrm{a}}$ & 11.0 & $15.3^{\mathrm{a}}$ & 10.0 \\
\hline Soy and other protein sources & 3.1 & 5.3 & 3.2 & 5.6 & 5.1 & 6.5 & 4.9 & 6.4 \\
\hline Energy premix & 15.6 & 11.3 & 14.5 & 14.4 & 12.5 & 16.4 & 13.0 & 17.9 \\
\hline Protein premix & $1.4^{\mathrm{b}}$ & 3.5 & $3.9^{\mathrm{a}}$ & 8.1 & $5.4^{\mathrm{a}}$ & 8.6 & $5.5^{\mathrm{a}}$ & 9.3 \\
\hline Supplements & 0.2 & 0.9 & 0.3 & 1.0 & 0.6 & 1.4 & 0.5 & 1.3 \\
\hline
\end{tabular}

${ }_{\mathrm{a}, \mathrm{b}}$ Means within a row with different superscripts differ $(P<0.05)$.

${ }^{1} \mathrm{PDO}=$ Protected Designation of Origin. 
Therefore, despite being small in size and low producing, $\mathrm{C} 1$ farms play a key role in the provision of ecosystem services such as biodiversity conservation and landscape maintenance (Sturaro et al., 2013; Zendri et al., 2013; Battaglini et al., 2014), which are vital for the economic survival of mountain resorts with a high touristic vocation (Gios et al., 2006). Also, for C1 and $\mathrm{C} 2$, cow longevity appears as an "iceberg indicator" of a satisfactory welfare status (Bruijnis et al., 2013; Heath et al., 2014) and, considering the predominant tiestall housing system, cow well-being certainly benefits from the diffuse practice of summer grazing (Corazzin et al., 2010; Arnott et al., 2017).

\section{Cow Feeding Plan}

The feeding plan of cows under the Asiago PDO chain is generally not intensive, with a forage:concentrate ratio ranging from 61:39 (C4) to 73:27 (C1). The relatively low concentrate intake could explain the lower milk yield per lactation registered in the different clusters compared with the average performances recorded for the reference breeds at the national level (AIA, 2017). Such a feeding system has positive effects on cow health and welfare by reducing the risk of subacute ruminal acidosis and of further diet-induced inflammations in the gut (Li et al., 2012; Khiaosa-Ard and Zebeli, 2018). Among clusters, $\mathrm{C} 1$ and $\mathrm{C} 2$ diets were substantially forage-based and corn silage represented only a minor share of their total DM. The mountain and hill locations of these farms precluded corn crop cultivation due to several environmental constraints such as altitude, soil slope, and the short vegetation season. In contrast, the lowland location of $\mathrm{C} 3$ and $\mathrm{C} 4$ farms was suitable for corn and cereals production, thus increasing farm availability of high-energy crops and supporting the choice of rearing high-producing dairy cows.

Differences in the diet composition have shown to affect milk and cheese lipid profiles; high-forage diets (especially pasture grazing) enrich milk and dairy products with mono- and polyunsaturated fatty acids, CLA, and fat-soluble vitamins such as $\alpha$-tocopherol and carotenoids, whereas corn silage increases the content of saturated fatty acids (Dewhurst et al., 2006; Fox et al., 2017; Segato et al., 2017). Grass and legume hay from local natural grassland and pasture were the main components of $\mathrm{C} 1$ diets and, together with the rearing of autochthonous breeds, characterized the "original traditional" dairy farms of this side of the Alps (Sturaro et al., 2013). Such a niche of producers should be officially certified by the PDO labels to support their survival. Based on the outcomes of this study, cheese factories supplied by $\mathrm{C} 1$ farms could market their dairy products with the additional quality label "mountain product," according to a recent regulation by the European Union (European Commission, 2012, 2014) that allows distinguishing agricultural products made in mountain areas within a given PDO.

Last, as the gastronomic culture of Italy and its agri-food products are recognized and appreciated by consumers all over the world, the use of geographical names, images, and trademarks that evoke "Italy" to market fake Italian products presents a severe form of unfair competition that damages the Italian exports and swindle the consumers (Carreño and Vergano, 2016). The results of this study and the proposed approach can help reinforce the fight against illegal PDO cheese imitations by providing information that can be included in their official production specifications.

\section{CONCLUSIONS}

This case study analyzed and clustered the farming systems that supply milk to the chain of a PDO cheese, Asiago. The outcomes highlighted that diverse farming systems may operate behind a single PDO product and that accurate knowledge is essential to identify the existence of particular niches of product or to plan for any improvement of its quality. In the specific case of the Asiago PDO, the analysis revealed the presence of a small cluster of farms $(\mathrm{C} 1)$ that has shown to provide essential ecosystem services for environment and biodiversity preservation in the alpine areas by rearing cattle of endangered breeds with feeding programs based on forages produced on-farm and on the use of pasture. Some of the information about the farming system upstream of the Asiago PDO dairy chain illuminated by this study may also support the fight against its illegal imitations, as Asiago is one of the most plagiarized cheeses around the world. From a methodological point of view, the analytical protocol of the present study might represent a benchmark for other cheese chains to provide a rigorous and transparent insight into their supplying farms. This approach has shown to be suitable to provide information about 2 issues of relevant interest for the consumers of dairy products, including the feeding program and the general welfare status of the cows.

\section{ACKNOWLEDGMENTS}

The authors acknowledge the bachelor students Elisa Rossetto, Martina Dal Santo, and Anna Fabris of the University of Padova for their skilled contribution to the data collection, input, and processing. A special thanks to Giovanni Rigon, technical supervisor of the Consortium for the Protection of Asiago Cheese, and to all the cheese factories' managers of the PDO chain 
for their active support during the farms' surveys. This work was supported by a grant of the Consortium for the Protection of Asiago PDO Cheese, Vicenza, Italy. The authors declare no conflict of interest.

\section{REFERENCES}

AIA (Italian Animal Breeders Association). 2017. On-line Bulletin. Accessed Aug. 2019. http://bollettino.aia.it/.

Arnott, G., C. P. Ferris, and N. E. O'Connell. 2017. Review: Welfare of dairy cows in continuously housed and pasture-based production systems. Animal 11:261-273. https://doi.org/10.1017/ S1751731116001336.

Balzan, S., L. Fasolato, B. Cardazzo, F. Montemurro, and E. Novelli. 2013. Preliminary findings on the effect of light-oxidation on Asiago d'allevo vecchio Protected Designation of Origin cheese. Ital. J. Food Saf. 2:e40. https://doi.org/10.4081/ijfs.2013.e40.

Battaglini, L., S. Bovolenta, F. Gusmeroli, S. Salvador, and E. Sturaro. 2014. Environmental sustainability of alpine livestock farms. Ital. J. Anim. Sci. 13:3155. https://doi.org/10.4081/ijas.2014.3155.

Bruijnis, M. R. N., F. L. B. Meijboom, and E. N. Stassen. 2013. Longevity as an animal welfare issue applied to the case of foot disorders in dairy cattle. J. Agric. Environ. Ethics 26:191-205. https:// doi.org/10.1007/s10806-012-9376-0.

Carreño, I., and P. R. Vergano. 2016. Geographical indications, "Food Fraud" and the fight against "Italian sounding" products. Eur. J. Risk Regul. 7:416-420. https://doi.org/10.1017/ S1867299X00005821.

Chavent, M., V. Kuentz-Simonet, B. Liquet, and J. Saracco. 2012. ClustOfVar: An R Package for the Clustering of Variables. J. Stat. Softw. 50:1-16. https://doi.org/10.18637/jss.v050.i13.

Clal. 2018. Production volumes of the Italian PDO Cheeses. Accessed Aug. 2018. https://www.clal.it/en/?section=formaggi_dop.

Consortium for the Protection of Asiago Cheese. 2006. Production specification, PDO "Asiago." Ministerial decree of 03/08/2006. Official Gazzette no. 190, 17/08/2006. Accessed Jun. 2020. https:// www.asiagocheese.it/en/consortium/production-rules.

Corazzin, M., E. Piasentier, S. Dovier, and S. Bovolenta. 2010. Effect of summer grazing on welfare of dairy cows reared in mountain tie-stall barns. Ital. J. Anim. Sci. 9:e59. https://doi.org/10.4081/ ijas.2010.e59.

Cozzi, G., and M. Bizzotto. 2004. Sustainability and environmental impact of the dairy production systems in mountain areas. Acta Agric. Slov. 84(Suppl.1):21-28.

Cozzi, G., J. Ferlito, G. Pasini, B. Contiero, and F. Gottardo. 2009. Application of near-infrared spectroscopy as an alternative to chemical and color analysis to discriminate the production chains of Asiago d'Allevo cheese. J. Agric. Food Chem. 57:11449-11454. https://doi.org/10.1021/jf9018905.

Dalla Riva, A., J. Burek, D. Kim, G. Thoma, M. Cassandro, and M. De Marchi. 2018. The environmental analysis of asiago PDO cheese: A case study from farm gate-to-plant gate. Ital. J. Anim. Sci. 17:250-262. https://doi.org/10.1080/1828051X.2017.1344936.

De Marchi, M., G. Bittante, R. Dal Zotto, C. Dal Vit, and M. Cassandro. 2008. Effect of Holstein Friesian and Brown Swiss breeds on quality of milk and cheese. J. Dairy Sci. 91:4092-4102. https:/ /doi.org/10.3168/jds.2007-0788.

Dewhurst, R. J., K. J. Shingfield, M. R. F. Lee, and N. D. Scollan. 2006. Increasing the concentrations of beneficial polyunsaturated fatty acids in milk produced by dairy cows in high-forage systems. Anim. Feed Sci. Technol. 131:168-206. https://doi.org/10.1016/j .anifeedsci.2006.04.016.

DOOR. 2018. Database of PDO, PGI and TSG. European Union. Accessed Aug. 2018. http://ec.europa.eu/agriculture/quality/door/ list.html?locale $=$ en.

Eastham, N. T., A. Coates, P. Cripps, H. Richardson, R. Smith, and G. Oikonomou. 2018. Associations between age at first calving and subsequent lactation performance in UK Holstein and Holstein-
Friesian dairy cows. PLoS One 13:e197764. https://doi.org/10 .1371/journal.pone.0197764.

European Commission. 2012. Regulation (EU) No 1151/2012 of the European Parliament and of the Council of 21st November 2012 on quality schemes for agricultural products and foodstuffs. Off. J. L343:1-29.

European Commission. 2014. Commission Delegated Regulation (EU) No 665/2014 of 11 March 2014 supplementing Regulation (EU) No 1151/2012 of the European Parliament and of the Council with regard to conditions of use of the optional quality term "mountain product." Off. J. L179:23-25.

Fox, P. F., T. P. Guinee, T. M. Cogan, and P. L. H. McSweeney. 2017. Fundamentals of Cheese Science. 2nd ed. Springer, New York, NY.

Gios, G., I. Goio, S. Notaro, and R. Raffaelli. 2006. The value of natural resources for tourism: A case study of the Italian Alps. Int. J. Tour. Res. 8:77-85. https://doi.org/10.1002/jtr.552.

Gulati, A., N. Galvin, E. Lewis, D. Hennessy, M. O'Donovan, J. J. McManus, M. A. Fenelon, and T. P. Guinee. 2018. Outdoor grazing of dairy cows on pasture versus indoor feeding on total mixed ration: Effects on gross composition and mineral content of milk during lactation. J. Dairy Sci. 101:2710-2723. https://doi.org/10 $.3168 /$ jds.2017-13338.

Heath, C. A. E., W. J. Browne, S. Mullan, and D. C. J. Main. 2014. Navigating the iceberg: Reducing the number of parameters within the Welfare Quality assessment protocol for dairy cows. Animal 8:1978-1986. https://doi.org/10.1017/S1751731114002018.

Khiaosa-Ard, R., and Q. Zebeli. 2018. Diet-induced inflammation: From gut to metabolic organs and the consequences for the health and longevity of ruminants. Res. Vet. Sci. 120:17-27. https://doi .org/10.1016/j.rvsc.2018.08.005.

Larsen, M. K., J. H. Nielsen, G. Butler, C. Leifert, T. Slots, G. H. Kristiansen, and A. H. Gustafsson. 2010. Milk quality as affected by feeding regimens in a country with climatic variation. J. Dairy Sci. 93:2863-2873. https://doi.org/10.3168/jds.2009-2953.

Lê, S., J. Josse, and F. Husson. 2008. FactoMineR: An R package for multivariate analysis. J. Stat. Softw. 25:1-18. https://doi.org/10 .18637/jss.v025.i01.

Li, S., E. Khafipour, D. O. Krause, A. Kroeker, J. C. RodriguezLecompte, G. N. Gozho, and J. C. Plaizier. 2012. Effects of subacute ruminal acidosis challenges on fermentation and endotoxins in the rumen and hindgut of dairy cows. J. Dairy Sci. 95:294-303. https://doi.org/10.3168/jds.2011-4447.

R Core Team. 2018. R: A language and environment for statistical computing. R Foundation for Statistical Computing, Vienna, Austria. https://www.R-project.org/.

Schievano, E., G. Pasini, G. Cozzi, and S. Mammi. 2008. Identification of the production chain of Asiago d'Allevo cheese by nuclear magnetic resonance spectroscopy and principal component analysis. J. Agric. Food Chem. 56:7208-7214. https://doi.org/10.1021/ jf801391w.

Segato, S., G. Galaverna, B. Contiero, P. Berzaghi, A. Caligiani, A. Marseglia, and G. Cozzi. 2017. Identification of lipid biomarkers to discriminate between the different production systems for Asiago PDO cheese. J. Agric. Food Chem. 65:9887-9892. https://doi.org/ 10.1021/acs.jafc.7b03629.

Sturaro, E., E. Marchiori, G. Cocca, M. Penasa, M. Ramanzin, and G. Bittante. 2013. Dairy systems in mountainous areas: Farm animal biodiversity, milk production and destination, and land use. Livest. Sci. 158:157-168. https://doi.org/10.1016/j.livsci.2013.09.011.

Zendri, F., E. Sturaro, and M. Ramanzin. 2013. Highland summer pastures play a fundamental role for dairy systems in an Italian alpine region. ACS Agric. Conspec. Sci. 78:295-299.

\section{ORCIDS}

I. Lora (1) https://orcid.org/0000-0001-8725-8597

L. Magrin $\odot$ https://orcid.org/0000-0002-2153-6117

G. Cozzi ๑ https://orcid.org/0000-0003-0408-1082 